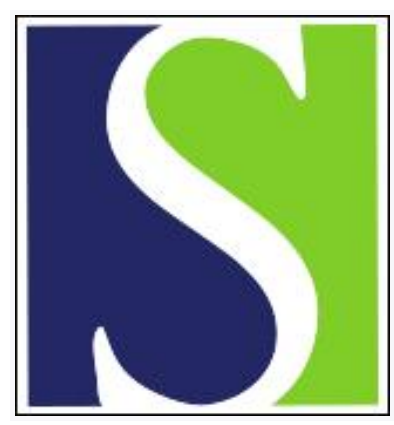

Scand J Work Environ Health 1977;3(2):80-90

https://doi.org/10.5271/sjweh.2786

Issue date: Jun 1977

Proposed biological threshold limit values for industrial exposure to trichloroethylene vapor.

by Gubéran $\mathrm{E}$

Key terms: biological monitoring; biological threshold; biological threshold limit value; industrial exposure; limit value; mathematical model; threshold limit; trhchloroethylene; trichloroacetic acid; trichloroethanol; trichloroethylene vapor

This article in PubMed: www.ncbi.nlm.nih.gov/pubmed/882860

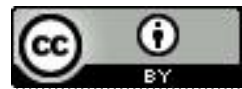




\title{
Proposed biological threshold limit values for industrial exposure to trichloroethylene vapor
}

\author{
by ETIENNE GUBÉRAN, M.D. ${ }^{1}$
}

\begin{abstract}
GUBERAN, E. Proposed biological threshold limit values for industrial exposure to trichloroethylene vapor. Scand. j. work environ. \& health 3 (1977) 80-90. A model was used for the simulation of the pharmacokinetics of inhaled trichloroethylene (TRI) vapor. Computed data of TRI in alveolar air and of trichloroacetic acid (TCA) and trichloroethanol (TCE) in blood and urine agreed satisfactorily with experimental results obtained by various authors. Biological threshold limit values were calculated for subjects exposed at rest to a steady concentration of $100 \mathrm{ppm}$ of TRI in ambient air, between 0800 and 1200 and between 1300 and 1700, five days a week during the whole year. The Monday to Friday range of values for urinary excretion (243-322 $\mathrm{mg}$ of TCA $/ 24 \mathrm{~h}$ and $288-429 \mathrm{mg}$ of $\mathrm{TCE} / 24 \mathrm{~h}$ ) roughly corresponded to the findings of several surveys among TRI workers in industry. The hypnotic effect of TCE and/or TRI during steady or fluctuating industrial TRI exposure was discussed with the aid of the model.
\end{abstract}

Key words: biological monitoring, mathematical model, trichloroacetic acid, trichloroethanol, trichloroethylene.

Since the publication of the first study using breath analysis to monitor trichloroethylene (TRI) exposure (36), several other studies have dealt with the determination of TRI in alveolar air and trichloroacetic acid (TCA) and trichloroethanol (TCE) in blood and urine $(9,17,25,26,35,37,38$, 39). During most of these studies subjects were exposed to a steady concentration of TRI vapor several hours a day for five consecutive days. This procedure is closer to the usual industrial situation than one single exposure per person, but results cannot be extended to exposures of more than one week, especially for TCA, which accumulates in the body. Studies on volunteers exposed under well-controlled conditions demand technical skill and a high outlay. The reproduction of condi-

1 Medical Advisory Service to the Factory Inspectorate, Geneva, Switzerland.

Reprint requesits to: Dr. E. Gubéran, Factory Inspectorate, Ferdinand Hodler 23, CH-1207 Geneva, Switzerland. ions usually observed in industry, such as exposures of several weeks or constant fluctuations of the ambient concentration, would not only be time consuming but also technically very difficult.

On the other hand, various mathematical models of the absorption, distribution, metabolism, and elimination (pharmacokinetics) of drugs have been developed, the general theory of which has been reviewed by Wagner (41) and, as far as inhaled anesthetics are concerned, by Mapleson (22).

The present study is an attempt to use such a model to fill the gap between experimental and industrial conditions. In order to examine whether the model was supported by experimental evidence, I have compared its results with those of experimental and industrial studies on TRI. Then I calculated "biological threshold limit values" by simulating industrial steady exposure to $100 \mathrm{ppm}$ of TRI, the present threshold limit value for airborne 
concentrations in most western countries. Finally some pharmacological effects of TRI absorption are inferred.

\section{METHODS}

For TRI I used a breath-by-breath model previously described (13) and developed along with experimental studies on tetrachloroethylene breath excretion (10). The physiological parameters of the model were modified with reference to the "preferred tissue volumes, blood flows and blood volume for a standard man" proposed by Mapleson (22). Alveolar ventilation $(5.85 \mathrm{l} / \mathrm{min})$ was calculated from the cardiac output of a standard man [6.5 $1 /$ min (22)] with the use of a ventilationperfusion ratio of 0.9 (6). The partition coefficients for TRI indicated by Steward et al. (34) were used (blood-gas: 9; tissuegas, visceral compartment: 20 (average), lean compartment: 12, fat: 600). A constant urinary flow of $1 \mathrm{ml} / \mathrm{min}\left(\begin{array}{lll}1.44 & 1 / 24 & \mathrm{~h}\end{array}\right)$ was postulated.

Experimental studies have demonstrated that TRI is first converted by liver microsomes to chloral hydrate $(\mathrm{CH})$ which is rapidly metabolized into $\mathrm{TCA}, \mathrm{TCE}$, and some unknown metabolites. TCE is then partially oxidized into TCA and both metabolites are excreted in the urine (TCE mostly after conjugation with glucuronic acid) $(3,4,23,26,29,30,33)$. On the other hand various volatile anesthetics have been shown to be metabolized at a rate related to their alveolar concentration. At lower levels, nearly all of the anesthetic is transformed as it traverses the liver (7).

The following scheme was therefore included in the model. All the hepatic blood flow is cleared of TRI, which is immediately converted into TCA $(15 \%)$, TCE $(51 \%)$, and unknown metabolites $(34 \%)$. TCA and TCE are diluted in body fluids and excreted in urine. (Apparent volumes of distribution and renal clearances are given in table 1.) Half of the excreted TCA is metabolized directly from TRI and half is oxidized from TCE (table 1). In the model this latter conversion occurs only when TCE is excreted in urine so that the delayed excretion of TCA, as yet not fully explained, will be simulated (26). (By a slight modification of the model, TCA is then reinjected into body fluids.) Experimental data in the literature on the metabolism and excretion of TCA and TCE conflict to a certain extent. An estimation was made from the studies quoted in table 1.

Table 1. Metabolism and excretion of trichloroacetic acid (TCA) and trichloroethanol (TCE): Data used in the model (estimated from the quoted literature).

\begin{tabular}{|c|c|}
\hline Hepatic metabolism $(23,26,29)$ & Urinary excretion $(3,23,29)$ \\
\hline TCA $15 \%$ & TCA \\
\hline TCE $51 . \% \stackrel{\overrightarrow{70.6 \%}}{\longrightarrow}$ & $\mathrm{TCE}+$ glucuronic acid $36 . \%$ \\
\hline ? $34 . \%$ & \\
\hline
\end{tabular}

\begin{tabular}{lll}
\hline & TCA & TCE \\
\hline Apparent volume of distribution (Vd) & $8.5 \mathrm{la}$ & $78 \mathrm{l}^{\mathrm{a}}$ \\
Renal clearance (Cl) & $1.3 \mathrm{ml} / \mathrm{min}(3,23$, & $75 \mathrm{ml} / \mathrm{min}^{\mathrm{b}}$ \\
Biological half-time (t1/2) & $29,33)$ & $12 \mathrm{~h} \mathrm{(26)}$ \\
\hline
\end{tabular}

\footnotetext{
a Calculated from $\mathrm{t} 1 / 2=\frac{\ln 2 \times \mathrm{Vd}}{\mathrm{Cl}}$.

b Estimated.
} 
Simulation with a digital computer was based on a simple system of equations. General equations of the exchange occurring during one respiratory cycle, in the case of a solvent eliminated only in the breath, have been given elsewhere (13). The introduced equations for hepatic metabolism and the urinary elimination of TCA and TCE are presented in the appendix.

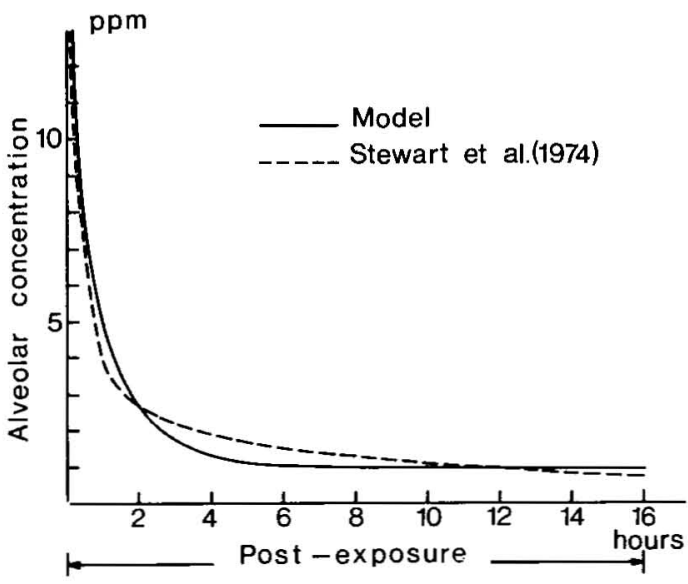

\section{RESULTS AND DISCUSSION}

As shown in fig. 1 , computed values of the postexposure TRI alveolar concentration and the 24-h urinary excretion of TCA and TCE satisfactorily agree with the mean values obtained by Stewart et al. (37). Similar agreement is observed with the data of a German group $(9,25$, 26), which also measured blood TCA and

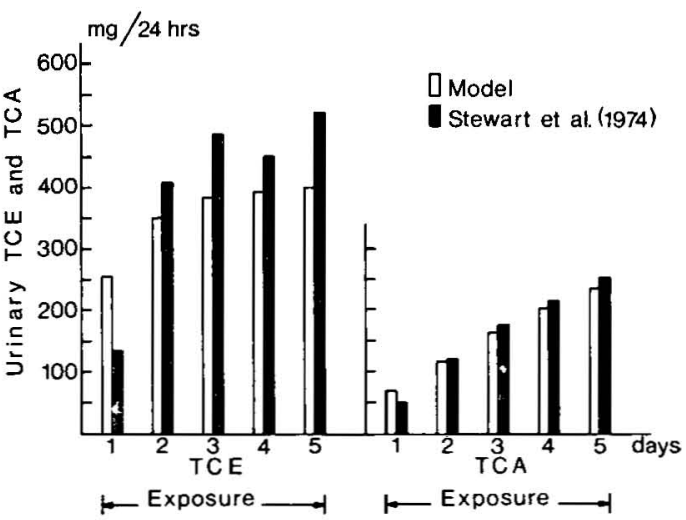

Fig. 1. Trichloroethylene alveolar concentration following exposure to $100 \mathrm{ppm} 7.5 \mathrm{~h}$ daily for 5 days and the 24-h urinary excretion of trichloroacetic acid and trichlonoethanol during exposure to $100 \mathrm{ppm} 7 \mathrm{~h}$ daily for 5 days. Comparison of the model with the data (mean of four and ten subjects, respectively) of Stewart at al. (37).

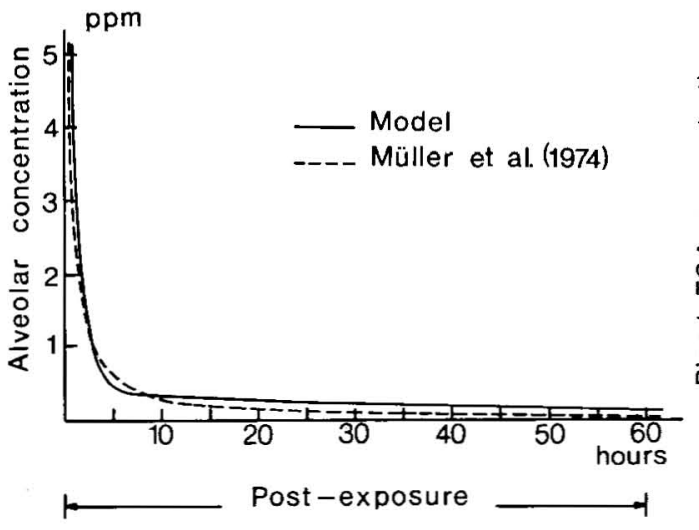

Fig. 2. Trichlonoethylene alveolar concentration following exposure to $100 \mathrm{ppm}$ for a period of $6 \mathrm{~h}$. Comparison of the model with the data (mean of five subjects) of Müller et al. (26).

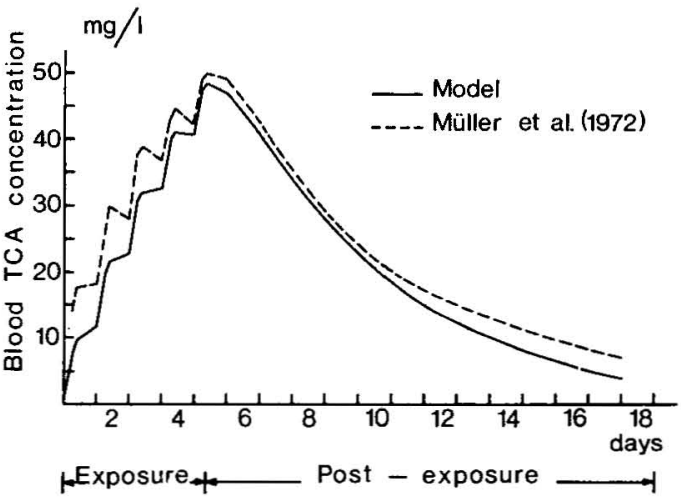

Fig. 3. Trichloroacetic acid blood concentration during exposure to $50 \mathrm{ppm}$ of trichloroethylene, $6 \mathrm{~h}$ daily for 5 -days. Comparison of the model with the data (mean of five subjects) of Müller et al. (25). 

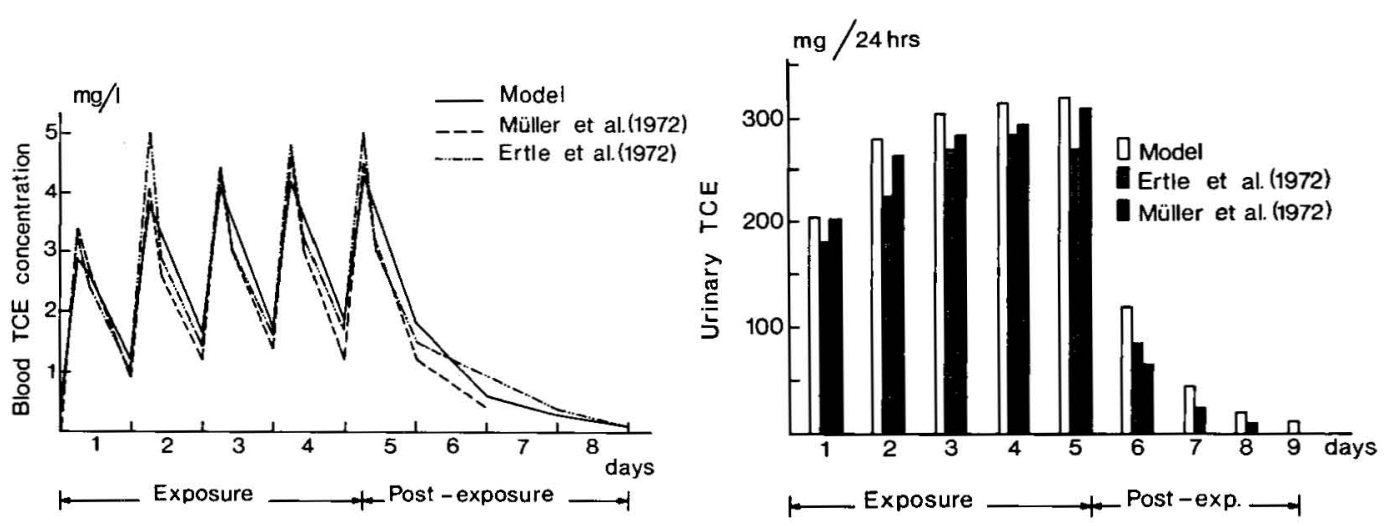

Fig. 4. Trichloroethanol (TCE) blood concentration and the 24-h urinary excretion of TCE during exposure to $100 \mathrm{ppm}$ of trichloroethylene $6 \mathrm{~h}$ daily for 5 days. Comparison of the model with the data (mean of five subjects) of Ertle et al. (9) and those (mean of five subjects) of Müller et al. (25). (Since the values of the latter corresponded to an exposure to $50 \mathrm{ppm}$, they have been multiplied by 2)

TCE (fig. 2, 3 and 4), and with the data of Kimmerle and Eben (17) (fig. 5). In both cases experimental values of TCA urinary excretion, not reported in the figures, show a trend similar to the computed values, but they deviate slightly more than for urinary TCE. Nevertheless account should be taken of the hypotheses of the model previously discussed (13) and of the expected biological variation, particularly the intersubject and intrasubject difference in biotransformation that has been reported for many drugs $(18,40)$ and for chloral hydrate itself (29).

Industrial exposure to $100 \mathrm{ppm}$ of TRI between 0800 and 1200 and between 1300 and 1700 five days a week was then simulated, and the predicted daily urinary excretion and blood peak concentration of TCA and TCE are shown in fig. 6. As can be seen, there was almost no further increase from the third to the fourth week for corresponding days. This result corresponds to an equilibrium state reached between the TRI retained and that eliminated through the lungs or metabolized during the latter week. Therefore the data of that week have been taken as "biological threshold limit values" for fulltime TRI workers exposed to little-fluctuating airborne concentrations averaging $100 \mathrm{ppm}$ (fig. 7 and table 2). These values, calculated for a standard man at rest,

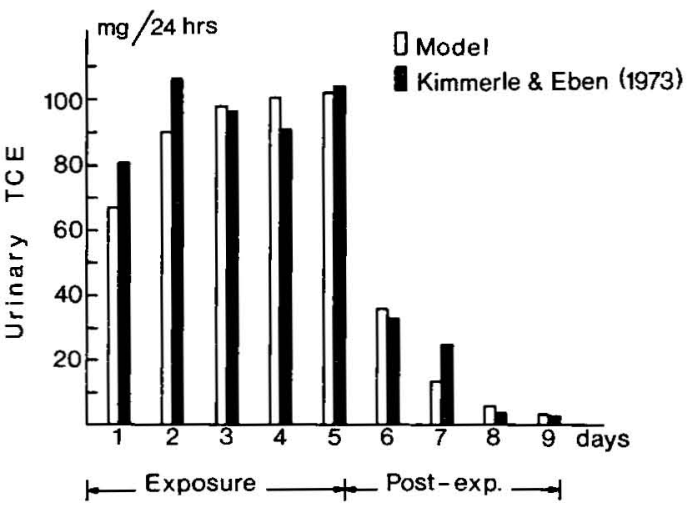

Fig. 5. The 24-h urinary excretion of trichloroethanol during exposure to $48 \mathrm{ppm}$ of trichloroethylene $4 \mathrm{~h}$ daily for 5 days. Comparison of the model with the data (mean of four subjects) of Kimmerle and Eben (17).

therefore correspond to basic conditions of pulmonary ventilation.

The question arises whether these values tally with the results of surveys made among TRI workers. Pfäffli and Backman (32) are the only ones who, in a preliminary report, have made analyses of TRI breath excretion from exposed workers, but their use of expired air measurements does not allow comparison with the alveolar concentrations predicted in the 


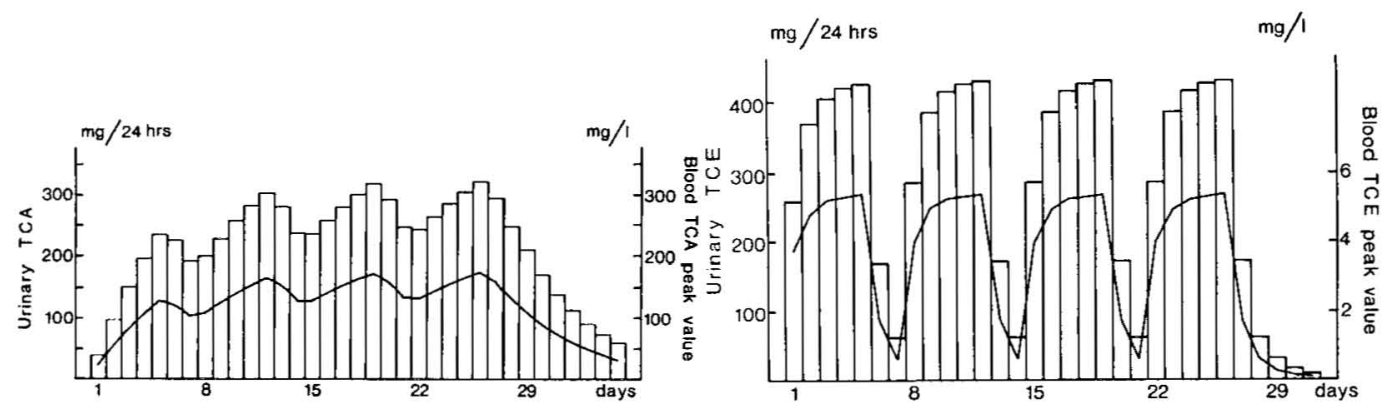

Fig. 6. Predicted values of the 24-h urinary excretion of trichloroacetic acid and trichloroethanol (histograms) and peak blood concentration (curve) during exposure to $100 \mathrm{ppm}$ of trichloroethylene, between 0800 and 1200 and between 1300 and 1700 five days a week for 4 weeks.
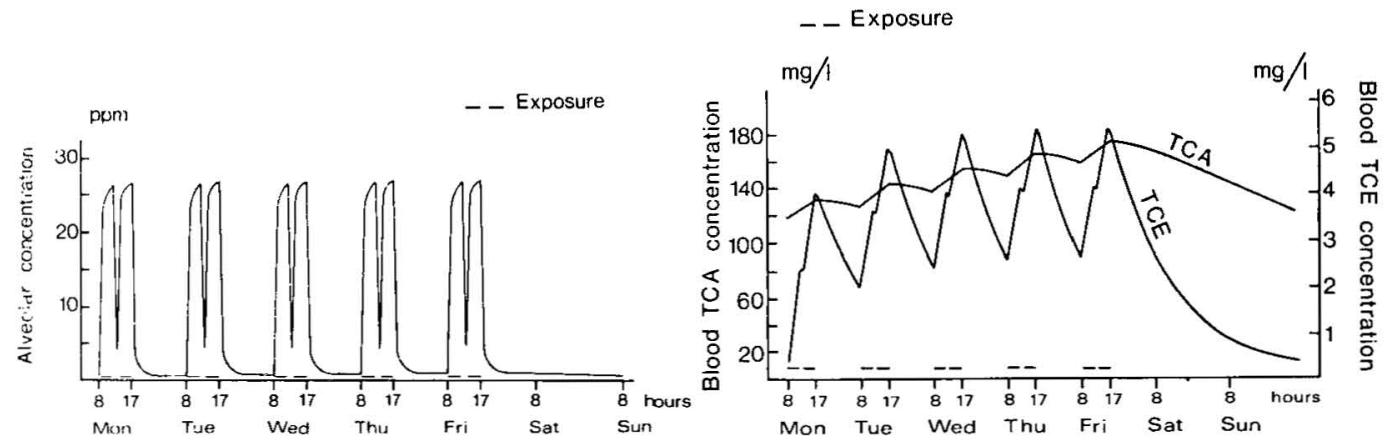

Fig. 7. Computed curves of trichloroethylene alveolar concentration and the trichloroacetic acid and trichloroethanol blood concentration for exposure to 100 ppm between 0800 and 1200 and between 1300 and 1700 five days per week. Values apply to the third and subsequent weeks of steady exposure.

model. No other data on alveolar TRI or blood TCA and TCE measured in industry are available at the moment, but several authors have attempted to correlate airborne TRI with the urinary TCA and TCE of full-time exposed workers. The mean values observed in these studies have been compared with the predicted values in table 3 .

The early surveys of Frant and Westendorp (11) and of Elkins (8) are in surprisingly good accordance with computed data, as well as that of Lindner (19) which was drawn up for one worker only, but for a period of 3 weeks. Mean results of Grandjean et al. (12) and of Ikeda et al. (15), on the contrary, differ from the predicted values. Finally, data of Lowry et al. (20), adjusted for urine concentration, are higher than expected for TCE and lower for TCA, but total trichlorocompounds (TCA + TCE) show a better concordance with predicted values. These three latter surveys show a wide scatter of individual results, and the authors have stressed uncertainty concerning the actual exposure of each worker. After this fact is taken into account, it can be concluded that urinary TCA and TCE predicted values roughly correspond to the findings of various studies among TRI workers. Also, it seems that observed and computed data agree better when total trichloro- compounds, rather than TCA or TCE alone, are used. 
Trichloroethylene exposure and chloral hydrate absorption

Chloral hydrate, "one of the best sedative and hypnotic drugs" (28), is the inter- mediate of TRI metabolism. Most and probably all of its long-lasting hypnotic effect is due to TCE (21). Chloral hydrate was shown to increase total sleep time and to decrease sleep latency in man at a

Table 2. Computed values of postexposure trichloroethylene alveolar concentration and of the 24-h urinary excretion of trichloroacetic acid (TCA) and trichloroethanol (TCE) for an exposure to $100 \mathrm{ppm}$ between 0800 and 1200 and between 1300 and 1700 five days per week. Values apply to the third and subsequent weeks of steady exposure of subjects at rest.

\begin{tabular}{|c|c|c|c|c|c|}
\hline \multirow{2}{*}{$\begin{array}{l}\text { Past- } \\
\text { exposure } \\
\text { time }\end{array}$} & \multicolumn{2}{|c|}{$\begin{array}{l}\text { Alveolar concentration } \\
(\mathrm{ppm})\end{array}$} & \multirow{2}{*}{ Day } & \multirow{2}{*}{$\begin{array}{c}\text { TCA } \\
(\mathrm{mg} / 24 \mathrm{~h})^{\mathrm{a}}\end{array}$} & \multirow{2}{*}{$\begin{array}{c}\text { TCE } \\
(\mathrm{mg} / 24 \quad \mathrm{~h})^{\mathrm{a}}\end{array}$} \\
\hline & Monday & Friday & & & \\
\hline $0 \mathrm{~min}$ & 26.8 & 27.2 & Monday & 243 & 288 \\
\hline $15 \mathrm{~min}$ & 8.0 & 8.5 & Tuesday & 264 & 385 \\
\hline $30 \mathrm{~min}$ & 6.4 & 6.8 & Wednesday & 286 & 414 \\
\hline $1 \mathrm{~h}$ & 4.3 & 4.8 & Thursday & 305 & 425 \\
\hline $2 \mathrm{~h}$ & 2.2 & 2.7 & Friday & 322 & 429 \\
\hline $3 \mathrm{~h}$ & 1.4 & 1.8 & Saturday & 296 & 172 \\
\hline $15 \mathrm{~h}$ & 0.6 & 1.0 & Sunday & 249 & 63 \\
\hline
\end{tabular}

a For conversion to $\mathrm{mg} / 1$ mulitiply by $0.694(1,000 \mathrm{ml} / 1,440 \mathrm{ml})$. (Computed constant urinary flow: $1 \mathrm{ml} / \mathrm{min}$ or $1,440 \mathrm{ml} / 24 \mathrm{~h}$ )

Table 3. Comparison of the predicted values of the urinary excretion of trichloroacetic acid (TCA) and trichloroethanol (TCE) with those observed among trichloroethylene workers exposed about 8 h daily.

\begin{tabular}{|c|c|c|c|c|c|c|c|c|}
\hline \multirow{3}{*}{ Authors } & \multirow{3}{*}{$\begin{array}{c}\text { Mean } \\
\text { exposure } \\
(\mathrm{ppm})\end{array}$} & \multicolumn{2}{|c|}{$\begin{array}{c}\text { Urinary TCA } \\
(\mathrm{mg} / \mathrm{l})\end{array}$} & \multicolumn{2}{|c|}{$\begin{array}{c}\text { Urinary TCE } \\
(\mathrm{mg} / \mathrm{l})\end{array}$} & \multicolumn{3}{|c|}{$\begin{array}{c}\text { Urinary TCA }+ \text { TCE } \\
(\mathrm{mg} / 1)\end{array}$} \\
\hline & & \multirow{2}{*}{$\begin{array}{c}\text { Ob- } \\
\text { served } \\
\text { (Mean) }\end{array}$} & Predicted & \multirow{2}{*}{$\begin{array}{c}\text { Ob- } \\
\text { served } \\
\text { (Mean) }\end{array}$} & Predicted & \multirow{2}{*}{$\begin{array}{c}\text { Ob- } \\
\text { served } \\
\text { (Mean) }\end{array}$} & \multicolumn{2}{|c|}{ Predicted } \\
\hline & & & Mon. Fri. & & Mon. Fri. & & Mon. & Fri. \\
\hline \multicolumn{9}{|l|}{ Frant and Westen- } \\
\hline Elkins (8) & 100 & 160 & $169-224$ & & & & & \\
\hline \multicolumn{9}{|l|}{ Grandjean et } \\
\hline \multirow[t]{2}{*}{$\begin{array}{l}\text { al. (12) } \\
\text { Lindner (19) }\end{array}$} & $\begin{array}{l}25 \\
41^{a}\end{array}$ & $\begin{array}{l}86 \\
83^{a}\end{array}$ & $\begin{array}{l}42-56 \\
69-92\end{array}$ & $114^{a}$ & $82-122$ & $197^{a}$ & $151-$ & 214 \\
\hline & & & & & & \multicolumn{3}{|c|}{$\mathrm{mg} / \mathrm{g}$ creatinine } \\
\hline \multirow[t]{3}{*}{ Ikeda et al. (15) } & 50 & $147^{\mathrm{b}}$ & 107 & 267 & 132 & 278 & & 191 \\
\hline & 120 & $230^{\mathrm{b}}$ & 257 & 682 & 316 & 519 & & 457 \\
\hline & & \multicolumn{2}{|c|}{$\mathrm{mg} / \mathrm{g}$ creatinine } & \multicolumn{2}{|c|}{$\mathrm{mg} / \mathrm{g}$ creatinine } & & & \\
\hline \multirow[t]{2}{*}{ Lowry et al. (20) } & $53^{a}$ & AM $48^{c}$ & 68 & 34 & 14 & 82 & 82 & \\
\hline & & PM $43^{c}$ & 72 & 145 & 99 & 188 & 171 & \\
\hline
\end{tabular}

a Mean was calculated in the present study.

b Urine collected in the latter half of the wee's at 1300. For the computed value the TCA and TCE urinary excretions were calculated for the period between 0800 and 1300 on Friday.

c Urine collected before and after the workshift on Monday. For the computed value the TCA and TCE urinary excretions were calculated for the period between 2300 and 0800 and for the period between 1200 and 1700 on Monday. Creatinine urinary excretion was assumed to be $1.25 \mathrm{mg} / \mathrm{min}$ at a constant rate during $24 \mathrm{~h}$. (Computed urinary flow: $1 \mathrm{ml} / \mathrm{min}$ ) 
dose of $0.5 \mathrm{~g}$ per day (14). Twice that dose $(15 \mathrm{mg} / \mathrm{kg})$ has resulted after nearly $1 \mathrm{~h}$ in a TCE peak blood concentration of about $7 \mathrm{mg} / \mathrm{l}(26)$ or $8 \mathrm{mg} / \mathrm{l}$ (33). The computed value of TRI retained per day during an industrial exposure to $100 \mathrm{ppm}$ $(1.12 \mathrm{~g})$ corresponds to an equimolar amount of $1.4 \mathrm{~g}$ of chloral hydrate, and the predicted TCE peak blood concentrations from Tuesday to Friday are about $5 \mathrm{mg} / \mathrm{l}$ at 1700 (fig. 7 and also fig. 4). Therefore the depressant effect on the central nervous system induced by such a "permissible" exposure might be stronger than that following the absorption of $0.5 \mathrm{~g}$ of chloral hydrate, the "usual hypnotic dose" (28).

Surveys on workers exposed to TRI have shown, not unexpectedly, that "abnormal fatigue" and "increased need of sleep" were the symptoms most commonly complained of (1). The impression of my coworkers and I, after interviewing many TRI workers, is that these and other prenarcotic symptoms are much more pronounced during the first weeks of exposure. This phenomenon can be attributed to the development of "tolerance," which implies a decreasing effect of a given dose of a drug after repeated administration. Tolerance has been observed with chloral hydrate (14), as well as with most narcotics and hypnotics, including $\mathrm{TCE}(16,24)$.

Hypnotic effect of trichloroethylene or trichloroethanol?

The preceding discussion raises the question of whether the hypnotic effect of TRI is exerted by TCE only. Observations during TRI analgesia and anesthesia might help to clarify this point. When TRI was administered at a concentration of $0.5 \%$, analgesia required about $1 \mathrm{~min}$ and the induction of surgical narcosis 10-15 min $(2,27)$. These rapid effects are explained better by the expected high TRI concentration in blood (and brain) than by the still very low TCE one, as shown in fig. 7 and 8. Also at the beginning of anesthesia a sharp rise of TRI arterial concentration was measured (5) and a slow increase in the TCE brain concentration was observed in an experiment with mice after intra- venous administration of chloral hydrate (21).

Whereas, after the cessation of exposure, the slow decrease of TCE blood concentration, contrary to the fall of TRI blood level (fig. 1, 2, 4, 7 and 8), might explain why the symptoms which the TRI workers complained of persist for a few hours (1) and why, after long TRI general anesthesia, some patients "slept for several hours postoperatively, although they had normal vital signs during this period" (31).

For industrial exposure as well as for general anesthesia it is therefore very likely that a short-term hypnotic effect due to the action of TRI itself is followed by a similar but more prolonged one due to TCE.

\section{Monitoring of industrial trichloroethylene exposure}

The last point to be discussed is whether the concept of "time-weighted average," which refers to airborne concentrations and is extensively used by industrial hygienists, is adequate for monitoring industrial TRI exposure.

It is very likely that the prenarcotic symptoms are associated with a threshold concentration of TRI in blood after the few minutes required for brain-blood equilibration. There is no evidence that a TRI blood concentration below the threshold could still induce the symptoms if it is maintained for a longer period.

As my coworkers and I have previously pointed out $(10,13)$, the level of the alveolar (or arterial) concentration versus time of a solvent is directly proportional to its constant inhaled concentration. Due to the sharp initial slope of the arterial TRI curve, if the airborne concentration rises suddenly during exposure, a similar increase of TRI concentration in arterial blood and well-perfused viscera will quickly follow. The effect of such fluctuations on the computed concentration of TRI in the vessel-rich tissues, including brain, is shown in fig. 8 .

Indicators related to the mean exposure, such as the time-weighted average of the airborne TRI concentration, TCA and TCE urinary excretion and late postexposure breath concentration, ignore the brief pe- 


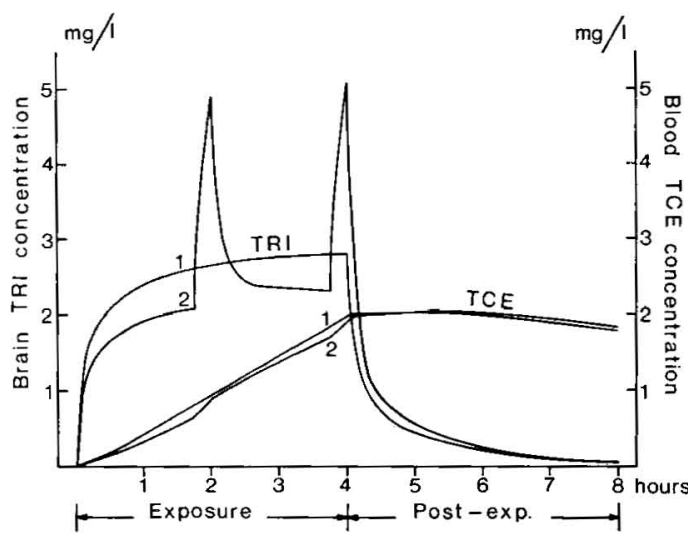

Fig. 8. Predicted trichlonoethylene brain concentration and trichloroethanol blood concentration during two exposures of the same timeweighted average airborne concentration. (1: $240 \mathrm{~min}$ to $100 \mathrm{ppm} ; 2: 105 \mathrm{~min}$ to $80 \mathrm{ppm}$ $15 \mathrm{~min}$ to $240 \mathrm{ppm}$ - $105 \mathrm{~min}$ to $80 \mathrm{ppm}$ $15 \mathrm{~min}$ to $240 \mathrm{ppm}$ )

riods when the "toxic threshold" is possibly exceeded. This possibility might explain the failure of observers to correlate the excretion of metabolites with prenarcotic symptoms and the appearance of the latter in many workers with very low levels of TCA urinary excretion $(1,12)$.

Such large fluctuations of airborne TRI concentration are likely to occur in degreasing and other industrial operations. Under these special circumstances analyses of frequent short-term samples of ambient air are necessary to monitor worker exposure to TRI, in addition to the measurement of the time-weighted airborne concentration and/or to biologic measurements.

\section{NOTE}

A Fortran program for the model will be published elsewhere with full explanatory comments and a discussion.

\section{ACKNOWLEDGMENTS}

I am grateful to Prof. G. Peters of the Pharmacological Institute of the Lausanne University (Switzerland) and to Prof. W. W. Mapleson of the Department of Anaesthetics, Welsh National School of Medicine,
Cardiff, for their encouragement and very useful advice.

\section{REFERENCES}

1. AHLMARK, A. and FORSSMAN, S. Evaluating trichloroethylene exposures by urinalyses for trichloroacetic acid. Arch. ind. hyg. 3 (1951) 386-398.

2. ATKINSON, R. S. Trichlorethylene anaesthesia. Anesthesiology 21 (1960) 67-77.

3. BARTONIČEK, V. Metabolism and excretion of trichloroethylene after inhalation by human subjects. $B r . j$. ind. med. 19 (1962) $134-141$.

4. BUTLER, T. C. Metabolic transformations of trichloroethylene. J. pharmacol. exp. ther. 97 (1949) 84-92.

5. CLAYTON, J. I. and PARKHOUSE, J. Blood trichloroethylene concentrations during anaesthesia under controlled conditions. Br. j. anaesth. 34 (1962) 141-148.

6. COTES, J. E. Lung function. Davis, Philadelphia, Pa. 1965, pp. 131 and 279.

7. EGER, E. I. (II). Anesthetic uptake and action. Williams \& Wilkins, Baltimore, Md. 1974, pp. 184-191.

8. ELKINS, H. B. Analyses of biological materials as indices of exposure to organic solvents. Arch. ind. hyg. 9 (1954) 212-222.

9. ERTLE, T., HENSCHLER, D., MÜLLER, G. and SPASSOWSKI, M. Metabolism of trichloroethylene in man. Arch. toxicol. (Berl.) 29 (1972) 171-188.

10. FERNANDEZ, J., GUBERAN, E. and CAPEROS, J. Experimental human exposures to tetrachloroethylene vapor and elimination in breath after inhalation. $A m$. ind. hyg. assoc. j. 37 (1976) 143-150.

11. FRANT, R. and WESTENDORP, J. Medical control on exposure of industrial workers to trichloroethylene. Arch. ind. hyg. 1 (1950) $308-318$.

12. GRANDJEAN, E., MÜNCHINGER, R., TURRIAN, V., HAAS, P. A., KNOEPFEL, $\mathrm{H} .-\mathrm{K}$. and ROSENMUND, H. Investigations into the effects of exposure to trichlorethylene in mechanical engineering. $B r . j$. ind. med. 12 (1955) 131-142.

13. GUBERAN, E. and FERNANDEZ, J. Control of industrial exposure to tetrachloroethylene by measuring alveolar concentrations: Theonetical approach using a mathematical model. $B r . j$. ind. med. 31 (1974) 159-167.

14. HARTMANN, E. and CRAVENS, J. The effects of long term administration of psychotropic drugs on human sleep: V. The effects of chloral hydrate. Psychopharmacologia 33(1973) $219-232$.

15. IKEDA, M., OHTSUJI, H., IMAMURA, T. and KOMOIKE, Y. Urinary excretion of total trichloro- compounds, trichloroethanol and trichloroacetic acid as a measure of exposure to trichloroethylene and tetrachloroethylene. Br. j. ind. med. 29 (1972) $328-333$.

16. JAFFE, J. H. Drug addiction and drug abuse. In: L. S. GOODMAN and A. GIL- 
MAN (eds.), The pharmacological basis of therapeutics. MacMillan, London, 1970, pp. 276-313.

17. KIMMERLE, G. and EBEN, A. Metabolism, excretion and toxicology of trichloroethylene after inhalation. Arch. toxicol. (Berl.) 30 (1973) 127-138.

18. LA DU, B. N. Genetic factors modifying drug metabolism and drug response. In: B. N. LA DU, H. G. MANDEL and E. L. WAY (eds.), Fundamentals of drug metabolism and drug disposition. Williams \& Wilkins, Baltimore, Md. 1971, pp. 308-327.

19. LINDNER, J. Felduntersuchungen in Lösungsmittelbetrieben. Zentralbl. Arbeitsmed. 23 (1973) 161-167.

20. LOWRY, L. K., VANDERVORT, R. and POLAKOFF, P. L. Biological indicators of occupational exposune to trichloroethylene. J. occup. med. 16 (1974) 98-101.

21. MAC KAY, F. J. and COOPER, J. R. A study on the hypnotic activity of chlonal hydrate. J. pharmacol. exp. ther. 135 (1962) $271-274$.

22. MAPLESON, W. W. Circulation-time models of the uptake of inhaled anaesthetics and data for quantifying them. Br. $j$. anaesth. 45 (1973) 319-334.

23. MARSHALL, E. $K$. and OWENS, A. H. Absorption, excretion and metabolic fate of chloral hydrate and trichloroethanal. Bull. johns hopkins hosp. 95 (1954) 1-18.

24. MAYNERT, E. W. and KLINGMAN, G. I. Acute tolerance to intravenous anesthetics in dogs. J. pharmacol. exp. ther. 128 (1960) $192-200$

25. MÜLLER, G., SPASSOVSKI, M. and HENSCHLER, D. Trichloroethylene exposure and trichloraethylene metabolites in urine and blood. Arch. toxicol. (Berl.) 29 (1972) $335-340$.

26. MÜLLER, G., SPASSOVSKI, M. and HENSCHLER, D. Metabolism of trichloroethylene in man Arch. toxicol. (Berl.) 32 (1974) 283-295.

27. NOWILL, W. K., STEPHEN, C. R. and SEARLES, P. W. Evaluation of trichloroethylene as an anesthertic and analgesic agent. Arch. surg. 66 (1953) 35-47.

28. OSOL, A. and PRATT, R. The United States dispensatory. Lippincott, Philadelphia, Pa. 1973, pp. 271-273.

29. OWENS, A. H. and MARSHALL, E. K. Further studies on the metabolic fate of chloral hydrate and trichloroethanol. Bull. johns hopkins hosp. 97 (1955) 320-326.

30. PAYKOC,, Z. V. and POWELL, J. F. The excretion of sodium trichloracetate. $J$. pharmacol. exp. ther. 85 (1945) 289-293.

31. PEMBLETON, W. E. Trichloroethylene anesthesia re-evaluated. Anesth. analg. (Cleve) 53 (1974) 730-733.

32. PFÄFFLI, P. and BACKMAN, A.-L. Trichlonoethylene concentrations in blood and expired air as indicators of occupational exposure: A preliminary report. Workenviron.-health 9 (1972) $140-144$.

33. SELLERS, E. M., LANG, M., KOCHWESER, J., LEBLANC, E. and KALANT, $H$. Intenaction of chlioral hydrate and ethanol in man. Clin. pharmacol. ther. 13 (1972) $37-58$

34. STEWARD, A., ALLOTT, P. R., COWLES, A. L. and MAPLESON, W. W. Solubility coefficients for inhaled anaesthetics for water, oil and biological media. $\mathrm{Br} . j$. anaesth. 45 (1973) 282-293.

35. STEWART, R. D., GAY, H. H., ERLEY, D. S. and DODD, H. C. Experimental human exposure to trichloroethylene. Arch. environ. health 20 (1970) 64-71.

36. STEWART, R. D., GAY, H. H., ERLEY, D. S., HAKE, C. L. and PETERSON, J. E. Observations on the concentrations of trichloroethylene in blood and expired air following exposure of humans. $A m$. ind. hyg. assoc. j. 23 (1962) 167-170.

37. STEWART, R. D., HAKE, C. L., LEBRUN, A. J., PETERSON, J. E., FORSTER, H. V., HOSKO, M. J., NEWTON, P. E., SOTO, R. J., DODD, H. C., GRAFF, S. A., DONOHOO, K. K. and MELLENDER, J. W. Biologic standards for the industrial worker by breath analysis: Trichloroethylene. (HEW publications (NIOSH) no 74133). U. S. Department of Health Education and Welfare, Washington, D. C. July 1974.

38. STEWART, R. D., HAKE, C. L. and PETERSON, J. E. Use of breath analysis to monitor trichloroethylene exposures. Arch. environ. health 29 (1974) $6-13$.

39. VESTERBERG, O. and ASTRAND, I. Exposure to trichloroethylene monitored by analysis of metabolites in blood and urine. $J$. occup. med. 18 (1976) 224-226.

40. WAGNER, J. G. Intrasubject variation in elimination half-lives of drugs which are appreciably metabolized. J. pharmacokinet. biopharm. 1 (1973) 165-173.

41. WAGNER, J. G. Do you need a pharmacokinetic model, and, if so, which one? $J$. pharmacokinet. biopharm. 3 (1975) 457478 .

Received for publication: 1976-10-08 


\section{APPENDIX}

Equations for the hepatic metabolism and urinary elimination of trichloroacetic acid and trichloroethanol

$$
\mathrm{W}_{\mathrm{TCE}}=\mathrm{W}_{\mathrm{TRI}} \times 0.51 \times \mathrm{X}
$$

where $\mathrm{W}_{\mathrm{TCE}}$ is the equimolar amount of TCE (mg) metabolized from TRI during the respiratory cycle, $W_{\text {TRI }}$ is the amount of TRI $(\mathrm{mg})$ passing through the hepatic artery and the portal vein during the respiratory cycle, and $\mathrm{X}$ is the ratio of molecular weight (mw) of TCE : molecular weight of TRI.

$$
\mathrm{W}^{\prime} \mathrm{TCA}=\mathrm{W}_{\mathrm{TRI}} \times 0.15 \times \mathrm{Y},
$$

as equation 1 but for TCA.

$$
\mathrm{WT}^{\prime}{ }_{\mathrm{TUE}}=\mathrm{W}_{\mathrm{TCE}}+\mathrm{WT}_{\mathrm{TCE}},
$$

where WT'TrE is the total amount of TCE $(\mathrm{mg})$ in body fluids after metabolization but before urinary elimination occurring during the respiratory cycle and WTTCEo is the amount of TCE (mg) in body fluids at the end of the preceding respiratory cycle.

$$
\mathrm{C}_{\mathrm{TCE}}=\mathrm{WT}{ }^{\mathrm{TCE}} / \mathrm{Vd}_{\mathrm{TCE}},
$$

where $\mathrm{CT}_{\mathrm{T}} \mathrm{E}$ is the concentration of $\mathrm{TCE}(\mathrm{mg} / \mathrm{l})$ in body fluids and VdT(E its apparent volume of distribution (1).

$$
\mathrm{WU}^{\prime}{ }_{\mathrm{TCE}}=\mathrm{C}_{\mathrm{TCE}} \times \mathrm{Cl}_{\mathrm{TCE}} /(\mathrm{f} \times 1,000)
$$

where WU'TCE is the kidney excretion of TCE $(\mathrm{mg})$ during the respinatory cycle, $\mathrm{Cl}_{\mathrm{T}(\mathrm{V}}$ is the renal clearance of TCE $(\mathrm{ml} / \mathrm{min})$, and $f$ is the number of respiratory cycles per minute (frequency of respiration).

$$
\mathrm{WU}_{\mathrm{TCE}}=\mathrm{WU}^{\prime} \mathrm{TCE} \times 0.706,
$$

where WUTrE is the amount of TCE (mg) eliminated in urine during the respiratory cycle.

$$
\mathrm{WT}_{\mathrm{T} \mathrm{TE}}=\mathrm{WT}^{\prime}{ }_{\mathrm{TCE}}-\mathrm{WU}_{\mathrm{TCE}}
$$

where WTT(E is the total amount of TCE (mg) in body fluids at the end of the respiratory cycle.

$$
\text { W'TCA }=\text { WU'TOE } \times 0.294 \times \mathrm{Z} \text {, }
$$

whene W"TYA is the equimolar amount of TCA (mg) metabolized from TCE during the respiratory cycle and $\mathrm{Z}$ is the ratio of molecular weight of TCA : molecular weight of TCE.

$$
\mathrm{WT}^{\prime} \mathrm{TCA}^{\prime}=\mathrm{W}^{\prime} \mathrm{TCA}+\mathrm{W}^{\prime \prime} \mathrm{TCA}^{+}+\mathrm{WT}_{\mathrm{TCAN}},
$$

as in equation 3 .

$$
\mathrm{C}_{\mathrm{TCA}}=\mathrm{WT}^{\prime} \mathrm{TCA} / \mathrm{Vd}_{\mathrm{TCA}},
$$

as in equation 4 . 


$$
\mathrm{WU}_{\mathrm{TCA}}=\mathrm{C}_{\mathrm{TCA}} \times \mathrm{Cl}_{\mathrm{TCA}} /(\mathrm{f} \times 1,000),
$$

where $\mathrm{WU}_{\mathrm{TCA}}$ is the amount of TCA $(\mathrm{mg})$ eliminated in urine during the respiratory cycle and $\mathrm{ClTCA}_{\mathrm{TCA}}$ is the renal clearance of $\mathrm{TCA}(\mathrm{ml} / \mathrm{min})$.

$$
\mathrm{WT}_{\mathrm{TCA}}=\mathrm{WT}^{\prime} \mathrm{TCA}_{\mathrm{C}}-\mathrm{WU}_{\mathrm{TCA}},
$$

as in equation 7 .

Remarks: WTTCE and WTTCA of a respiratory cycle become $\mathrm{W}_{\mathrm{TCE}}$ and $\mathrm{W}_{\mathrm{TCA}} \mathrm{Ao}$ of the next respiratory cycle. In figs. $3,4,7$, and 8 the bloot TCA concentration was drawn from $\mathrm{C}_{\mathrm{T} C \mathrm{~A}}$ (equation 10) when the blood TCE concentration [ $\mathrm{C}_{\mathrm{TCE}}$ (true value)] was obtained from: $\mathrm{C}_{\mathrm{T}(\mathrm{E}}$ (true value) $=\mathrm{WU}_{\mathrm{T}(\mathrm{E}} \times \mathrm{f} \times 1,000 / \mathrm{Cl}_{\mathrm{TC}} \mathrm{E}$. 